\title{
AN OVERVIEW ON THE ABUSE OF POWER IN THE PERSPECTIVE OF CORRUPTION LAW AND GOVERNMENT ADMINISTRATION LAW IN INDONESIA BASED ON THE CRIMINAL JUSTICE SYSTEM AND THE STATE ADMINISTRATION OF THE JUSTICE SYSTEM
}

\author{
Seno Wibowo Gumbir; Ratna Nurhayati SH M Hum \\ Legal Studies Program, Faculty of Social Science and Political Science \\ Email: seno@ecampus.ut.ac.id, anna@ecampus.ut.ac.id
}

\begin{abstract}
The abuse of power in Indonesia has been regulated in the realm of administrative law at the Law Number 30 Year 2014 on Government Administrationand Law Number 31 Year 1999 jo Law Number 20 Year 2001 on The Corruption Eradication. The arrangement in those lawshas created an overlapping, overcriminilization and disharmony of law. This can be seen in Law No 30 Year 2014 on Goverment Administration,the sanctions of the abuse of powerare simply to return loss and can also be accompanied by dismissal, while in Law No 31 Year 1999 jo Law Number 20 Year 2001 onthe Eradication of Corruption with or without loss can be imprisoned and returning the loss will not remove the criminal prosecution. Other than that, there are potential linkage in the test to determine a state officials discretions between the Administrative Court and the Constitutional Court Post Pretrial Judicial Review Decision to extend the authority of the Pretrial.
\end{abstract}

Keywords: the Abuse of Power, Goverment Administration Law, Corruption Eradication Law

\section{A. INTRODUCTION}

The concept about a state of law has emerged and popular in the XIX century as a reaction to the arbitrariness that happened in the past (Ni'matul Huda. 2005: 1). The Constitution of 1945 has reflected the concept of thought that uphold the human rights and guarantee the rights of all citizens are equal before the law and the government, as well as the obligation to uphold the law and the government without any exception. According to Sri Soemantri a constitutional state must meet several elements, those are :

1) The Government in carrying out its duties and responsibilities should be based on law or legislation;

2) The guarantee of the human rights (for citizens);

3) The division of power in the state

4) The supervision of the justice agencies (Sri Soemantri. 1992:29).

The Republic of Indonesia is basically a state of law, means that the concept of Pancasila law is essentially has the elements contained in the rechtsstaat concept and the rule of law concept. With the combination of those concepts, would for sure have the consequence that the State shall guarantee the rights and obligations as well as legal protection against all parts of Indonesia. One of the most important elements from the state of law is that the 
government in carrying out its duties and responsibilities should be based on law or legislation (Sri Soemantri, 1995: 29).

The state apparatus throughout the world, including Indonesia in performing their functions, duties and authorities is referring to the main legal instrument of positive law. This is to prevent arbitrary action and also for the bureaucracy movement in government can runnsmoothly in accordance with the service standards that have been set by the government, so that the public interest can be served by the best, so in this case the restrictions on the power are needed.

The restriction on the government (executive) power in administrative law area is not only based on the principle of legality. The restrictions on the government power or state administration officials are also done through other methods or mechanisms. It appears in the form of restrictions on the government power or state administration officials who are bound or free (discretion) (Hotma P. Sibuea. 2010: 141).Thefree restrictions on thegovernment power or state administration

officials are done through some policy testing mechanism determined for the governments or officials of state administration.

State officials in carrying out its functions, especially the function of the state administration are certainly understood that the administrative law gives a discretionary power- "vrijbestuur ", " Freies ermessen "- to carry out "beleid"in order to run the duties and responsibilities of the government (O.C. Kaligis. 2012:130).

The core of the problems that deal with the discretion now are that the state officials from the ministerial level to regents or all public officials are scared to take or make a policy, this is due to the concerns that they would get affected by the problem or dealing with the law enforcement officials. This is understandable because since entering the reformation era until now there has been many state officials from ministerial level to regents or city government officials even villages affected by the criminalization discretion that has been created and run. For example, in 2015 there were 2 Governors of Bank Indonesia, 18 Governors, one Indonesia National Army General and from the National Police Officersthere were 1 four-star general and 3 three-star generals, besides that from the legislative House of Representatives there were more or less than40, more than 200 mayors and regents also had some legal problems in the realm of criminal and had to go to jail.

In 2014 was born theLaw Number 30 Year 2014 on Goverment Administration that expected to be a legal basis protection of state leaders who issued a discretion in serving and providing services to meet the public interest. But in 2016 semester 1, some state officials affected or 
suspected corruption at the level of investigation, based on ICW's report there were 217 suspects from Bureaucrats area, 107 suspects from Director / President / Consultant, 24 suspects from the members of theHouse of Representative /Assembly at Regional/Leadership of Political Party at Regional Level, 14 suspects from officials state /local enterprises, 10 suspects fromvillage chief/Subdistrict head, 7 suspects from the regional head. While in the period 2010-2015 there were a total of 110 suspects. They were 16 suspects from the Regent and the Vice Regent, 34 suspects from mayor, 7 suspects from deputy mayor, 14 suspects from Governor and two suspects from Deputy Governor (Media Indonesia. 2016. Pemerintah Daerah Menjadi Episentrum Kasus Korupsi. Tertanggal 29 Agustus 2016 Page 5).

Then there were 8 suspects from the non-ministry institutions, 7 head officer ofBUMN, 7 KPU (General Election Comission), 7 districts / sub-districts , 6 universities, 5 Regional House of Representatives ${ }^{1}$. With so many state officials dragged into a criminal law is possibly occurred by the discretion that has been issued and run. Some of state officials who issued the discretions and then draggedinto the problems of criminal like in the case of Burhanuddin Abdullah, Syahril Syabirin, Akbar Tanjung, Three Former Directors of Bank Indonesia, Bank Mandiri's Directors Noel and friends, Case Sisminbakum who also involved Yusril Ihza Mahendera and Romli Atmasasmita on that time and the last in the case of Bank Century. Not to mention there is currently village fund program which has been implemented to build the villages, it is also potentially caused the village policies (discretion)into a criminal law problem.

With the concerns of the state officials to issue a discretionary certainly will indirectly affect the tasks and functions in developing countries, that impact of slowing the infrastructure development and also can lead to a stagnant economic growth. Whereas the policy (discretionary) is in the realm of administrative law, but the fact that the policy is being criminalized, creating the impression that discretion is in the gray zone. Thus certainly creates a perception that there is no clear limit to when a policy decision (discretion) and its implementation, which can be imprisoned and that can not be criminalized.

The Problems are added with the two regulatory provisions of the law with a different realm that regulate the abuse of power. The abuse of power has been set in the Law Number 30 Year 2014 onGoverment Administration and Law Number 31 Year 1999 JoLaw Number 20 Year 2001 on Corruption Eradication.

\section{B. PROBLEM STATEMENT}

Based on those things, the important issues to be focused on are that: The problems studied in this paper is the view reflection of the discretion that contains the abuse of power 
elements by state officials in terms of the Law of Corruption andGoverment Administration Law, in this case is to find out if a discretion contains an abuse of power element, can it be included in a state administration law especially the Goverment Administration Law or can it be included in the criminal law especially the Corruption Eradication Law? The testing includes comparing the provisions of the legislation both from the standpoint of material law and formal law in order to provide legal certainty.

\section{RESEARCH METHODS}

This study uses a normative method, which is Explorative-analytical. The data used is secondary data, in the form of primary legal materials and secondary law (Soerjono Soekanto dan Sri Mamuji. 2007: 52). Method is needed to conduct a scientific research. Method means to gain the informations in a planned and systematic way. The measures taken must be clear, and have a strict limitation in order to avoid miss-interpretation. To assess the existing problems, this research uses juridical doctrinal approach, the approach that sees the law as a doctrine or asa normative set of rules. This approach is done through the efforts of the assessment or legal research literature. In this case the author analyzes comparative law, principles of law, the norms of positive law, and the opinion of scholars or jurists.

The data used in this research is secondary data such as documents, books, scientific works and papers, magazines and other journals. After the secondary data collected then analyzed qualitatively to analyze and answer the problem.

\section{DISCUSSION}

\section{Review on Abuse of Power by State Administrator in the Perspective of State Administration Law and Corruption.}

Since the reformation era in Indonesia, corruption eradication has been masively done because of the increasing number of corruption act, collusion and nepotism during the New Order agethat ruled for 32 years. The prosecution of corruption in Indonesia is running effectively but requires some tests whether the entire prosecution of corruption that involves many state officials have reflected the balance of theory with practice and a sense of fairness? Of course, that kind of question will arise and thought by the majority of academics and practitioners who participated in the eradication of corruption, especially concerning a discretion bysuspected state officials which contains elements of Power abuse. Before the Law Number 30 Year 2014 On Government Administration formed, a discretion can be 
included into the realm of criminal law, especially the Corruption Law, this can be seen from some of the cases as follows:

1. The case of the former chairman of the Investment Coordinating Board (BKPM) Theo F Tuemion in the case of the investment program or Indonesia Investment Year 20032004 program. This program was implemented to increase the investment number inIndonesia, that was experiencing an economic crisis and investment as a result of the Bali bomb tragedy. He was first investigated on 7 December 2005 and was arrested on 28 December 2005. The Corruption EradicationCommission (KPK) considered that Theo violated the Article 2 (1) and Article 3 of Law Number31 Year 1999, as amended by Law 21 Year 2001 on Corruption Eradication (http://www.hukumonline.com/berita/baca/hol14123/theo-toemion-jadi-tersangkakorupsiaccessed on 6 juni 2015). At the trial judge Moefri said Theo was not applied the tenders procedure in the implementation of investment projects. According to the judge that act is violated the law (https://nasional.tempo.co/read/news/2006/08/25/05582614/theo-toemion-divonis-6 tahunaccessed on 6 Juni 2015). _And then, he was put on trial at the Corruption Court on 20 April 2006 and Toemion was sentenced to six years in prison by the Special Court for Corruption on 25 August 2006. On 1 March 2007, the Supreme Court rejected the petition of cassation. The appeal panel kept sentenced him to six years in prison and ordered to pay a substitute for corruption losses of $\mathrm{Rp} 23.115$ billion within a month or would be replaced by imprisonment for five years https://id.wikipedia.org/wiki/Theo_Toemion\#Kasus_korupsiaccessed on 6 Juni 2015).

2. The case of Rokhmin Dahuri, who served as Minister of Maritime Affairs and Fisheries, for being corruption-related cases of non-budgetary funds (unauthorized charges) in Department of Marine and Fisheries (DKP) during 18 April 2002 to 23 March 2005. The non-budgetary funds were come from the donations of Echelon I and the head of the Provincial used for the benefit of institutions not for personal interest, and even the entire mechanism and the flow of funds was recorded and accounted well. At the level of the First Court and Appeal and Cassation found guilty of corruption and sentenced to seven years in prison or a fine of Rp. 200 million by the Corruption Court in Jakarta July 2007. On the reexamination of the level of judicial review verdict became 2.5 year sentence 
(http://www.jpnn.com/read/2012/12/11/149981/Rokhmin-Dahuri,-Bekas-Menteriyang-Pertama-Dijerat-KPK-accessed on 6 September 2015).

3. Case of PT. Bank Mandiri with E.C.W Neloeand friends as defendants that legally should be an administration violation in giving the loan. By providing the load to borrowers that later caused the loan stuck. The judges rate of Cassation Number 1144K / Pid / 2006 dated 13 September 2007 decided to sentence each defendant to 10 years (Jongker Sihombing. 2009: 111).

Moreover, in the practice, many judges were conducting the act against the law in Article 2 of the Law Corruption Eradicationthat follows the act against the material law in a positive function with the act againts the law in Article 3 of the Law Corruption Eradication. As we know that the thought of against the material law in a positive function means that even if the act is not regulated by legislation, but if the act is considered reprehensible because it does not correspond to the sense of justice or fairness norms or norms of social life of the community, so that such acts can be punished (Lilik Mulyadi, 2012: 23). Thus there is an effect that works against the material law in a positive function, of course there are elements that are against the law in the formulation of the offense will cover all violations of law in the realm of civil law or in the realm of administration. The negative result that happenes on the level of practice not only will overlap the interpretation between law enforcement agencies, even opens the possibility of criminalization of public officials (Nurbasuki MinarNumber, 2010: 58).

In fact, the provision in Article 2 (1) and Article 3 of the Law Corruption Eradication scope of the act againts the law is very different. According to Nur Basuki Minarno, implicitly the power abuse inherent with the act againts the law. Due to abuse their power/ authority is essentially an act against the law. Elements against the law is its genus, and the power abuse element is its species ${ }^{2}$. Implicity inherent between formele wederrechtelijkheid with abuse of power does not, mutatis mutandis, both of them are identical. This opinion was caused by the abuse of power as the core of the offense in Article 3 of the Law Corruption Eradication and against the law is a core part of the offense in Article 2 of the LawCorruption Eradication (Nurbasuki MinarNumber, 2010: 58). However, even theoretically the concepts of its legal fight is different, but still the judges create theelement of act againts the law between Article 2 (1) and Article 3 of the Law Corruption Eradication.Eventhough 
theoretically different and actually teachings unlawful nature of material in a positive function has been judicially reviewed and was decided by the Constitutional Court (MK) in 2006 through its decision Number 003 / PPU-IV / 2006 dated July 25, 2006 which stated that Article 2, paragraph 1 Law Number 31 Year 1999 Jo Law Number 20 Year 2001 on Corruption Eradication was clashed with the Constitution of 1945 in particular on Article 28 letter D and not legally binding. But although the Constitutional Court (MK) has stated that Article 2 (1) of the Law on Corruption Eradication was not legally binding, the Supreme Court judges still use it, it was stated by Lilik Mulyadi with the following argument:

1) After the Constitutional Court decision shows the explanation of article 2, paragraph (1) of Law Number 31 Year 1999jo Law Number 20 Year 2001 affected unlawful material act since is not regulated and does not have a strong base as a legal protection. That kind of consequences and implications will cause a normative provisions of Article 2 Paragraph (1) of Law Number 31 year 1999 jo Law Number 20 year 2001 becomes unclear normatively and unclear implications. Strictly speaking, the unlawful act in corruption cases are exist in the society but on the other hand, does not normatively set in legislation since the legal protection in the acts against the law as described by the provisions of Article 2 (1) of Law Number 31 year 1999 jo law Number 20 year 2001 by the decision of the Constitutional Court Number 003 / PUU-IV / 2006 dated July 25, 2006 has been "amputated" because it is not in line with the 1945 Constitution and not legally binding.

2) In the fixed jurisprudence(vaste jurisprudentie) adopted a long time within the judicial practice turned out to be the Indonesian Supreme Court has determined the existence of an unlawful act of material both in the negative function (Supreme Court of the Republic of Indonesia Number: $42 \mathrm{~K} / \mathrm{Kr}$ / 1965 dated January 8, 1966, Decision Supreme Court Number: 71 / K / 1970 dated May 27, 1972, Supreme Court Decision Number: 81 / K / Kr / 1973 dated May 30, 1977) as well as the positive function (Supreme Court of the Republic of Indonesia Number: 275 K / Pid / 1983 dated December 29 1983, the Supreme Court of the Republic of Indonesia Number: 2477 K / Pid / 1988 dated July 23, 1993, the Supreme Court Decision Number 1571 K / Pid / 1993 dated 18 January 1995). The logical consequence dimensions brings some kind of polarization of thought that the Supreme Court wants to punish in 
accordance with the paradigm of the principle of justice which even though was not regulated in the Law but since the practice in the community regarded as a disgraceful act, so it can not be tolerated and the perpetrator should be sentenced as the norms that live in society (living law) with keep using the principles of justice parameters.

3) Examining from the perspective of the criminal policy, the judges as the policy holder must apply the laws and regulations. Because of those dimensions, the judges are not only meant to be a mouth of the Law(bouche de la loi)but the judges also have to act as a filter and implementing these abstract regulations toward the concrete cases. The logical consequence that the judges willface is the choice of fairness, certainty, and expediency. On the one hand, formal act of corruption (formal act againsts the law) does not exist, but on the other the material act of corruption (material act againsts the law) does exists, so as the applicative policy the judges must explore, understand and uphold the legal norms that live in the community. If it iselaborated further, the paradigm perspective above is because the judges living in the community also explore and establish laws for society. Rules are made to a society and of course to be sentenced in accordance with the dimensions of the supporting community justice where the law is living. In the modern paradigm can now be mentioned with the paradigm that " the judges do not live in an ivory tower" (Lilik Mulyadi. 2012).

From Lilik Mulyadi's arguments, the reasons why the Supreme Court keeps applying the thought of unlawful material in the positive function after the judicial review decision of the Constitutional Court, the author concludes that:

1) First, although there is no legal protection, the judges may perform a legal discovery which is certainly in line with the decision of the Constitutional Court, since the decision of the Supreme Court judges in terms of hierarchy was not commensurate with the Constitutional Court decision which are in the same rank as the Law, as described previously, So the judge should not be used to against the law material in a positive function, because it is binding all the litigants as well as the state elements, the citizens and the state institutions. It was also stated by Ali Muchammad Safa'at that ordinary court decision stating that only binding on some parties, the Constitutional Court 
Decision in the case of testing the Law should be binding on all components of the nation, both state officials and citizens (Muchamad Ali Safa'at, 2015: 2), or known as the principle of erga omnes, the Constitutional Court decision can not be separated from the principle of erga omnes which has legally binding on all components of the nation, so that all parties must obey to implement the decision (Syukri Asy'ari, Meyrinda Rahmawaty Hilipito, Mohammad Mahrus Ali, 2012).With the Decision of the Constitutional Court, so the act againsts the material law in a positive function can not be used as a legal basis for criminalizing the discretion of state officials.

2) Second in this case as we know that the legal principle will not have the binding force if it is not in the form of positive law, it is based on "Rechtsprinzipien sind leitende Gedanken einer (moglichen order bestehenden) rechtlichen Regelung, die selbst noch keine der 'Anwendung 'faehige Regeln sind, aber in solche umgesetzt warden können ". (The principles of law is the idea that guides the rule of law (which may exist or has existed), which it is not a rule that can be applied, but which can be changed) (J.J.H. Bruggink,1999: 119). Other than that, when the Constitutional Court sated a phrase against the material law in Article 2 (1) does not have the binding force, so the transitoir legal principles (transition) will be applied as in Article 1 (2) of the Criminal Code which states "If the regulations law changed after the deed is done, the most favorable provision to the defendant will be applied". That changing phrase is of course based on the unlimited material theory that all of the changing reasons either change because changes in the legal sense of the legislators and change because a situation has passed,including a change in the meaning of Article 2 (1) Criminal Code. It is used in order to protect the people's interests from the arbitrary actions by the rulers. Do not let the rules that will come after is heavier imposed on the defendant. But it will be applied instead if profitable (Andi Hamzah. 2012: 72). This problem is focuses on the human Rights protection as stated by Andi Hamzah.

3) Third, concerning discretionary powers misuse of the State officials itself,the Supreme Court has applied the doctrine against the material law in a negative function as in the Decision of corruption of Machrus Effendi M.A's case. dated January 8, 1966, Reg. No 42 K / KR / 1965 and the corruption of Ir. 
Otjo Danuatmadja (M.A. dated March 20, 1977, Reg. Number 81 K / KR / 1973), Decision No 591 MA K / ery / 2010 December 21, 2010 with the defendant Prof. Dr. Romli Atmasasmita, SH, LLM in case ofSisminbakumof the Justice and Human Rights Ministry. So that the Supreme Court can use the doctrineagainsts the material law in the negative function when meet all of the components such as the defendants do not get any benefit, public interest is served, the state finance is not harmed so the defendants will be free from the lawsuit. The fourth, when observed from the criminal law point of view as presented by Eddy OS Hiariej stated"by doing the act againsts the material law in the negative function is a justification and therefore according to him, he can accept it (Eddy OS Hiariej, 2016: 248). While in nature of against the material law in a positive function is aclashed to the principle of legality and thus he can not accept it since it would create a legal uncertainty (Eddy OS Hiariej, 2016: 248), then he added apart from the clashed with the principle of legality, he also suggested that if this is clashed to the fundamental principles of the crime law evidence which reads, actori incubit onus proband, non probante actor, reus absolvitur.Means that those who claim are obliged to prove, if it can not be proved, the accused must be released. Strictly speaking, if the public prosecutor in a criminal case can not prove the offense elements of which the accused defendant (actore non probante), then the defendant must be acquitted (reus absolvitur) (Eddy OS Hiariej, 2016: 248).

4) The fourth is concerning about those actions are deemed reprehensible because it does not in line to the sense of justice or the norms of justice and norms in social life of the community in the criminal law, Andi Hamzah said the notion is in contrary to the norms that live in the community, a research must be done beforehand, how do the teachers, the head of customs, the head of the eligions, etc., about the worth or not is an act deemed as an act againsts the material law. Andi Hamzah opinions have been expressed and taken into consideration in the decision of the Constitutional Court judicial review Number 003 / PPU-IV / 2006, "referring to the unwritten laws in the size of propriety, prudence and thoroughness that live in the community, as a norm of justice is a measure of uncertainty, and vary from one community to the other communities. So what is against the law in one place might elsewhere be accepted and recognized as legitimate and legal according to the 
measurement known in the local community life, as stated by Andi Hamzah as an expert witness in the trial" (Chaerudin, Syaiful Ahmad Dinar, Syarif Fadilla, 2008: 11). In this case, author agrees because in formulating a provisions formulation in criminal law to declare an act is a criminal offense should be done through some research first.

After discussing the problem of compounding doctrine against the law, the question arises whether the element of power abuse is contained in the provisions of the Corruption Law and there are some overlapping and disharmony in terms of both the formulation and the legal consequences and sanctions in the Government Administration Law? When compared and presented in table 1 can be seen as follows:

Table1

The Comparison of Power Abuse Provisions between the Goverment Administration Law and the Corruption Eradication Law.

\begin{tabular}{|c|c|c|}
\hline Criteria & Goverment Administration Law & Corruption Eradication Law \\
\hline \multirow[t]{4}{*}{ Legal basis } & $\begin{array}{l}\text { Article } 17 \text { ayat (1) and (2) of } \\
\text { theGoverment Administration Law. } \\
\text { Goverment officials are not allowed to } \\
\text { abuse the power that they have, which } \\
\text { covers: (a) exceed the power, (b) } \\
\text { confound the power, (c) do arbitrary } \\
\text { act }\end{array}$ & \multirow[t]{4}{*}{$\begin{array}{l}\text { Article } 3 \\
\text { Every person who has the intention } \\
\text { to benefit him/herself,other persons } \\
\text { or a corporation is abusing the } \\
\text { power,chances orfacility that he/she } \\
\text { has because of a potition that can } \\
\text { harm the state finance or state } \\
\text { economy, }\end{array}$} \\
\hline & $\begin{array}{l}\text { Article } 18 \text { (1) of Goverment } \\
\text { Administration Law explains more } \\
\text { detail about the criteria of exceeding the } \\
\text { power that if the discretion done over: } \\
\text { (a) the lenght of service or the authority, } \\
\text { (b)the borderlin of the authorityand or } \\
\text { (c) against the legal provision. }\end{array}$ & \\
\hline & $\begin{array}{l}\text { Article } 18 \text { (2) of Goverment } \\
\text { Administration Law mention that the } \\
\text { criteria of confounding the authority is } \\
\text { if it meets the elements(a) outside the } \\
\text { coverage area or the material authority } \\
\text { given (b) against the goal of the } \\
\text { authority given }\end{array}$ & \\
\hline & $\begin{array}{l}\text { Article } 18 \text { (3) of Goverment } \\
\text { Administration Law a discretion } \\
\text { catagorized by the arbitrary act is if it } \\
\text { meets the criteria of (a) done without } \\
\text { thebasic authority and or (b) against the } \\
\text { court ruling which has a fixed legal } \\
\text { force. }\end{array}$ & \\
\hline
\end{tabular}




\begin{tabular}{|c|c|c|}
\hline \multirow[t]{4}{*}{$\begin{array}{l}\text { Legal } \\
\text { consequence }\end{array}$} & $\begin{array}{l}\text { Article } 19 \text { (1) Toward exceeding the } \\
\text { length of service or the authority length } \\
\text { of service, against the } \\
\text { legislations, without the basic } \\
\text { authority,against the court ruling which } \\
\text { has a fixed legal force. So the legal } \\
\text { consequece is an invalid legal } \\
\text { consequence. }\end{array}$ & \multirow[t]{4}{*}{$\begin{array}{l}\text { shall be punished with imprisonment } \\
\text { for life or imprisonment of a } \\
\text { minimum of } 1 \text { (one) year and a } \\
\text { maximum of } 20 \text { (twenty) years and } \\
\text { or a fine of Rp. } 50,000,000.00 \text { (fifty } \\
\text { million rupiah) and Rp. } \\
1,000,000,000.00 \text { (one billion } \\
\text { rupiah). }\end{array}$} \\
\hline & $\begin{array}{l}\text { Article } 19 \text { (2) Outside thecoverage } \\
\text { areas of authority given or against the } \\
\text { goal of authority given, then the legal } \\
\text { consequence is in the form of } \\
\text { irrevocable. }\end{array}$ & \\
\hline & $\begin{array}{l}\text { Article } 20(6) \text { if there is a loss to the } \\
\text { state because of an administrative } \\
\text { error by the abuse then charged to the } \\
\text { government officials concerned }\end{array}$ & \\
\hline & $\begin{array}{l}\text { Article } 80 \text { paragraph (1) Jo Article } 81 \\
\text { Paragraph (3) Government officials } \\
\text { who violate the provisions in Article } 17 \\
\text { (Prohibition of Abuse of Authority) and } \\
\text { Article } 42 \text { (Discretion is the Conflict of } \\
\text { Interest) incur a heavy administrative in } \\
\text { the form of: } \\
\text { 1) Fixed termination by acquiring } \\
\text { the rights to financial and other } \\
\text { facilities; } \\
\text { 2) Fixed termination without } \\
\text { acquiring the rights to financial } \\
\text { and other facilities; } \\
\text { 3) Fixed termination remain with } \\
\text { the obtaining of financial rights } \\
\text { and other facilities as well as } \\
\text { published in the media } \\
\text { 4) Fixed termination without } \\
\text { acquiring the rights to financial } \\
\text { and other facilities as well as } \\
\text { published in the media. }\end{array}$ & \\
\hline
\end{tabular}

On Government Administration Law in Article 17 about the types of power abuse in the form of (a) exceeds authority, (b) confound authority, (c) act arbitrarily which has the legal effect that the invalid legal consequences and may be canceled. In Article 20 (6) shall be declared if there are losses that occur due to administrative error caused by abuse of power, then charged to the government officials concerned that may also lead to a sanction. This 
means that if there is abuse of power that cause the state loss, the sanctions will be returning the loss and can also be added to sanctions as stipulated in Article 80 (3) which is the termination.

While, in Article 3 on Corruption Eradication there are some aspects of abusing the power that could harm the country's finances. What is meant by "abusing" is a very broad sense and is not limited coverage in a limited asthe provisions of Article 52 of the Criminal Code. According to Lilik Mulyadi, concretely "abusing" here can be interpreted in the perspective of using their rights and powers inapropriately such as only profitable for their children, grandchildren, family or friends (Lilik Mulyadi. 2007: 93). Furthermore, he stated about the "misuse of opportunity", here it can be interpreted as the misuse of time or opportunity for themselves for the existence of their position, while "misuse of facility" means that there appears to be misuse of equipment or facilities that attached on the offender for a position as a state employee. Meanwhile, according to Sudarto, the term "notch" next to the word "position" is dubious. If the position here is defined as functions in general, a director of a private bank also has a position ${ }^{3}$. Meanwhile, about the state's financial losses in the concept of Article 3 of the Law on CorruptionEradicationaccording to Komariah Emong Sapardjaja, said that Law Number 31 Year 1999 embraced the concept of state losses that interpreted as make the state bears a loss directly or indirectly. It means, an action automatically could be considered causing the loss to the state if that action is potentially causing the loss to the state. Thus, the presence or absence of state losses in real terms to be unimportant and then he said that the word 'could' before the phrase 'financial harm or state economy' shows that corruption is a formal offense, that the existence of corruption is enough if meets the elements formulated not the consequences (Sudarto. 1981: 142).So enough with the fulfillment of the abuse of power elements then an administration official who abuses their power/authority may be subjected to Article 3 of the Law on the Corruption Eradication and what if there is indemnification of the state losses conducted by the State or government officials? Surely if it is seen from the Law on Corruption Eradication in Article 4 which states "In the event that the perpetrators of corruption as referred to in Article 2 and Article 3 has met the elements of those Articles, the indemnification of state financial or the country's economy, do not abolish the crime towards the perpetrators". Stillrelation with the state loss and its contradictory with statement from Romli Atmasasmita in a seminar on the Indonesian Judge Association March 2015 Post-Law Number 30 Year 2014 of the 
GovermentAdministration, stated that the act of maladministration by APH and state administrator does notmutatis mutandis, is a corruption,considering it also has a correlation with the Treasury Law and state financial that regulating the state losses as in the provisions of Part XI of the State losses settlement/regions Article 59 (1) states that any losses your country/region should be settled in accordance with the provisions of the legislation in force and in paragraph (2) of the article mentions the treasurer, civil servants who are not a treasurer or other officials not required to compensate theState/areas. Furthermore, in Article 60 states that any legal subjects who caused the state / region losses must be requested to make a letter of intention and a recognition that the loss is their responsibility and willing to pay the losses (Romili Atmasasmita in OC. Kaligis. 2015: 92).

Therefore, in those two law provisions indicated that there is a dissynchronized (disharmony), inappropriate and causing an overlapping between one legal norm and another legal norm between Government Administration Law and Corruption Eradication Law. This happens because of the disharmony on both arrangement that manage about the abuse of power and its sanctions are different from one another, this is because the arrangement in the Government Administration Law was completed only up to the administrative sanction stagethat is to pay the losses of his state by the Officer who abuses the power/ authority and possibly followed with termination sanction. Whereas, in the Corruption Eradication Law by abusing the power/ authority that aims to benefit themselves, another person or corporation may be punished and if any indemnification of the statelosses, it does not abolish the punishment. With the disharmony can result in:

1) The occurrence of different interpretation in the implementation;

2) The emergence of legal uncertainty;

3) Legislation is not done effectively and efficiently;

4) Law dysfunction, means that the law can not do its function to provide guidance to the public behaviors, social control, dispute resolution, and as a means of social change (Iman Suroso. 2016: 157-158).

Besides disharmony can potentially overlapping and overcriminilization that has some impact. First, as stated by Bambang Purnomo, "that needs to remember, on one hand, criminal law and its implementation required as a means to achieve the purpose of the law to create peace because criminal law is a powerful way to tackle crime, but on the other hand the criminal law and its implementation can be harmful to individuals and wider society because it contains the dimensions of absolutism with the tendency of "overcriminilization" 
and "crime infection". So that the criminal law will be useless if its existence and implementation does not focus on efficiency and effectiveness in the community" (Bambang Poernomo 1988: 164). Second, with the overcriminalization of course the law can not achieve its goals which is the development of the country in all fields and this is in line with what Martin Luther King Jr. stated,"Law and order exist for the purpose of establishing justice and when they fail in this purpose they become the dangerousely structured dams that block the flow of social progress" (http://www.brainyquote.com/quotes/quotes/m/martinluth297518.htmlaccessed on 15 Juni 2016).

1) For solve the disharmony and overlapping laws and overcriminilization understanding and distinction are needed toward the term abuse their power/authority as stipulated in the Government Administration Law and the CorruptionEradication Law have different meanings. As in Supreme Court Decision Number 977 K / PID / 2004 which adopted the theory ofde autonomic van het materiels stafrecht (the autonomy of criminal law material) of HA Demeersemen that stated if any word or the same terminology, the criminal law has the autonomy to provide understanding which is different from the definition contained in the other branches of the law, but if the criminal law does not specify it, the sense in other branches of law will be used. Therefore, if a sense of power abuse can not be found explicitly in criminal law, the same terminology contained in or derived from other branches of law can be used (Indriyatno Seno Adji, 2009: 43). Therefore, if the notion of abusing power not explicitly found both in the realm of criminal law, the criminal law can use the notion of abusing the power contained in the realm of state administrative law.As known in the realm of science study of administrative law, according to Jean Rivero and Waline can be interpreted in the form as follows:

1) Abuse of power to perform acts that clashed to the public interest or for the benefit of personal interests or groups;

2) Abuse of power in the sense that the actions of officials of the state administration is really for the public interest, but clashed with the purpose of the power given by law or other regulations;

3) Abuse of power in the sense of misusing the procedures that should be used to achieve certain goals, but to use other procedures to be implemented (Jean Rivero dan Waline in Ridwan.2014:177). 
Therefore abusing of authority as contained in Article 3 of the Corruption Eradication Law has a pattern assessment to determine whether there is abuse of power against the law which refers to the opinion of Jean Rivero and Waline above, especially in the form of the number 1, which acts of misuse the power issued by government officials are given with the intent and purpose to enrich themselves, another person or corporation that contain elements of corruption, collusion and nepotism, while the loss of the state is not an absolute requirement in Article 3 of the the CorruptionEradication Law. Meanwhile, abuse of power stipulated in the Law on Government Administration refers to the form of number 2 and 3 in this case, because a welfare state, state interference in people's lives can not be avoided. Considering of how much duty in serving the public that has to be implemented, it is clear that the officials of the state administration requires freedom of movement, especially to face the urgent issues. While the rule does not yet exist or have not been clear so that it requires a step that sometimes violated the procedure in order to reach and meet the public services andpublic interest, that is the public officials will run the duty to uphold the principles of internal morality of law proposed by Fuller that "the rule must be understandable to Reviews those to Whom they apply." (Joel Feinberg. 2003: 12).In addition, since because in the Netherlands and Indonesia, the procedure violations are classified as an act againsts the regulations, not a pure abuse of power that against the law. Parameters used is also different. Parameter abuse of power is the principle of specialty, whereas the parameter ofprocedural violation is the laws and the regulations. In addition, based on the elucidation of Article 53 (2) of Law Number 5 Year 1986 ofThe Administrative Court declared that a procedural violation was classified as "contrary to the provisions of the legislation that are procedural / formal" (Ridwan, 2014: 178).

In addition to the distinction terminology of abuse of power contained in the Goverment Administration Law and the CorruptionEradication Law as described previously, of course, should be noted also that the Government Administration Law with the Corruption Eradication Law are equally a lex specialistthat of course there will be a problem. In the development of law-including the legal law principle of lex spesialis derogate generalican not resolve the disputes in case of juridical act that threatened more than one law that qualified as bijzoner delic or special offense or a special criminal act ${ }^{4}$. If so, then the principle ofsystematic lex will be used as a derivative of the principle of lex specialist derogate 
general $^{5}$. The criteria of systematic lex is the object of the general definition is more completely set in the framework of special provisions (Eddy OS Hiariej 2016: 416-417). Actually, the principle of specialist systematica lex regulated in Article 14 of the Law Corruption EradicationLaw which states "Any person who violates the provisions of the Law which assertively states that the violation of the Law provisions such as corruption will be charged with the sanctions stipulated in this Law ". But the problem is sometimes or many Law Enforcer waive or pretermit Article 14 of the Law Corruption Eradicationand with the two provisions which regulate the abuse of power stipulated in the CorruptionEradication Law and the Goverment Administration Law, the nature and position of the criminal law need to be considered before applying the specialist systematic lex, this is because in usingthe sanctions/punishments needs to consider the limits of administration criminal sanctions. The use of criminal law with the negative sanctions is seen as choices or subsider,by promoting other types of sanctions in law first (M Alli Zaidan, 2016: 346). This means that as long as the Government Administration Law can cope with the behavior of power abuse that has no bribery, graft and extortion elements, so the CorruptionEradication Law used as an ultimum remedium and the Corruption Eradication Law may also be premium remedium if it meets the requirements stated by HG De bunt "the victim is enormous, the residivist defendant, losses is irreparable (H. G De Bunt in Romili Atmasasmita. 2010: 192). Therefore the application of the principle of specialist systematic lex as a means of solving the abuse power problems between the Government Administration Law and the CorruptionEradication Law conducted with the conditional provisions such as the Government Administration Law as the primer decision in its use towards the power abuse done by the state officials as long as there areno elements of bribery and graft and extortion, while if there are elements of bribery, graft, extortion, nepotism and collusion in power abuse act accompanied by the aspects of enormous victims, the defendant residivist and losses can not be recovered (irreparable), so the provisions of CorruptionEradication Law will be as well as the change ofultimium remediuminto remedium premium. It is also considering the placement of criminal sanctions as a premium remedium, must be done carefully and selectively by considering the objective conditions that related to the deeds, subjective things related to the offender, people thought towards the criminal acts and the objective of the punishment that trying to reach (Muladi, 1990: 48). 
With the distinction of terminology and application of the specialist systematic lex principle by considering various aspects above, it is expectedthat the law enforcement officials able to distinguish the meaning of the abuse of power in the realm of criminal law and in the realm of goverment administrative law, because if not, it can lead to overlapping, overcriminilization as well as legal disharmony with the result that has been described above.

\section{The Correlation Between Absolut Testing Competency In Determining The Presence} of Abuse of Power Elements In A Discretion By PTUN With Pretrial Investigation In Assigning The Validity Of The Suspect After The Constitutional Court Judicial Review Decision

In Goverment Administration Law, to decide whether or not there is an element of power abuse in a discretionary, a state official must fulfill the elements of such a discretion created and implemented by the board or government officials, have been inspected or supervised by the Government Internal Supervisory Apparatus (APIP), the monitoring results stated that there was an administrative error causing losses to the state occurred because of the abuse of power elements as stipulated in Article 17 and 18 of the Goverment Administration Law.

In Article 21 of the Goverment Administration Law, the examination or the right to sue of the state officials to determine whether there are elements of power abuse in a discretionary by the board or the State Officials is a manifestation of the principle of equality in law both as individuals and in a position qualifications as a state official, so in this case state officials in the Administrative Court can examine its discretion through as Petitioner or respondent. Other than that, Article 21 emerged due to the absence of a defense forum for boards or state officials suspected of abuse of power other than in the realm of criminal law and they feel victimized by the criminalization of policy towards the public officials. Criminalization happens against the policies of public officials, can cause legal uncertainty, even in the broader perspective can undermine the law itself because it has superiorized a particular legal aspect in this case is the criminal law and asserted the functions and roles that should be followed by legal aspects /domain such as civil law and goverment administration law and other segments (Moch Iqbal. 2014: 103).

Since there is a decision of the Constitutional Court Number 21 / PUU-XII / 2014, the Pretrial can examine and decide upon the legitimation of the suspect. This potentially make anabsolute overlapping competention between the PTUN and the Pretrial. Because the 
Pretrial in deciding the legitimation of the suspects will examine the suitability of the evidence and fundamentals used by investigators in determining the suspects, the example ofPretrial examination request about the legitimation of the suspects for former chairman of the State Audit Agency, Hadi Purnomo in the case of abusing the power in granting the BCA bank tax objections and granted a pretrial stipulation it unlawful determination of the suspect until the level of judicial review in the Supreme Court (http://nasional.kompas.com/read/2016/06/28/17363961/ma.tolak.pk.yang.diajukan.kpk.atas. praperadilan.hadi.poernomoaccessed on 28 Juni 2016). The second wasin the case of PDAM (Loca Water Supply Utility)installation with the suspect former Mayor of Makassar, Ilham Arief Sirajuddin which in South Jakarta Pretrial decided that the determination of the suspect by the KPK was invalid and void by the law (http://www.gresnews.com/berita/hukum/210125-/0/accessed on 1 Januari 2016)

. However, given that in practice every pretrial decision that has the force of the law is not always obeyed by the law enforcement plus another with the decision of the pretrial investigation can still be done by issuing warrant investigation again it will cause the problem of legal uncertainty.

Other problem is what if there are already inkracht decisions of the administrative court discretion testing against state officials and those are not set as abuse of power but still criminalized by the state administrative law enforcement? This has happened already as an example in the case of Determination of the suspect by the KPK by using Article 2 (1) and Article 3 of the CorruptionEradication Law, the Southeast Sulawesi Governor, Nur Alam in the case of abuse of power in publishing IUP when the establishment authorized of discretion has been tested by PT. Prima Nusa Sentosa in the Administrative Court in its decision the Supreme Court decided that the issuance of the IUP in accordance with the procedure provided in Article 37 letter b of Law Number 4 of 2009 on Mineral and Coal (http://news.detik.com/berita/3300015/tak-terima-jadi-tersangka-kpk-gubernur-sultra-nuralam-ajukan-praperadilan accessed 16 september 2016 ). Of course, this raised the question of whether there is legal certainty and legal protection for officials or state officials who take or remove the discretion?

Regarding the discretion test, the Supreme Court (MA) issued a regulation called Perma Number 4 Year 2015, especially in Article 2 (1) that says the Court is authorized to receive, examine and decide upon the assessment whether there is any misuse of authority in decisions or actions of state officials before the process criminal. With the provisions of this then how the limits of the process? In this case Zudan Arif Fakrullah said in terms of 
administrative court decision which has permanent legal force said that there was no abuse of power, so the officials can not be examined in the perspective of criminal, civil and administrative. Whereas, if the judge of Administrative Court (PTUN) in his decision stated that officials were proved guilty of misusing his authority/power then the door for law enforcement officials to take him to the criminal realm and into the realm of law was allowed (Zudan Arif Fakrullah. 2015: 13). But it is different from the opinion of Yulius who stated that the PTUN only authorized to examine the elements of power abuse limited only to an administrative error of agency or government officialsin term ofthe fulfillment of power abuse elements or not as referred in the Article 17 and 18 of the Goverment Administration Law (Yulius. 2015, 20) $)^{6}$.

On the above issues and the judiciary, which has the competence to examine whether or not a power abuse act actually being addressed through the National Meeting of the Supreme Court which was held on 2-6 September 2007 in Makassar which basically argued:

1) A policy is a matter of "freedom of policy" (beleidsvrijheid, Freies ermessen) of the state apparatus in carrying out the public duties, so it can not be judged by the judge of criminal or civil judges. If it is linked with the policy application (beleidsvrijheid, wijsheid, Freies ermessen, beleidsregels), then the administrative penal law is not included in the domain of corruption.

2) Beleidsvrijheid and wijsheid held by any officials or state officials, who have the authority under the legislation that exists. Restrictions on Beleidsvrijheid apply ifthere are acts that included in abuse of authority/power(detourne-ment de pouvoir and abus de droit). The resolution of these irregularities, done through the administrative tribunals or state administration tribunal.

3) Freies Ermessen used by officials or state officials to act within the framework of an important and urgent solution, which arise and encounter in the country, and should be carried out in order to achieve national objectives. Restrictions on the use of freies Ermessen are parameters the general principles parameters of good governance.

4) Beleidsregels may not exceed or eliminate the hierarchy of legislation, because beleidsregelsis outside the hierarchy of legislation

5) Those policies are only obeyed and judged in terms of administrative law and constitutional law, because it is an administrative law domain. The policy can not be judged by judges, both in terms of the application of public law (criminal) and in terms of private law (civil). It is because the policies of this administration has legal parameters that can only be examined from the aspects ofrecht-matigheid and not dolmatigheid. In this case, the corruption Eradication law can not be applied, because the administrative aspects of the penal law relating to the products or policies given the legal authority by the state administration (Andhi Nirwanto. 2015: 222-223) 
With regarding the aspects above, the authors take the middle way that in the event of a discretion of public officials or state officials who have been tested and decided by the administrative court to be declared null and there are no elements of power abuse, or in accordance with the procedures and have a permanent legal force, it can not be proposed and applied to the realm of criminal law, especially corruption. Unless law enforcement officials found new evidence in the form of the presence of elements of bribery, graft, collusion and nepotism, enormous victims, defendant residivist, losses can not be recovered (irreparable) at the discretion that has the elements of power abuse, it can be submitted to the realm either through a pretrial criminal law and criminal law enforcement proceeding. This is to avoid the judicial competence overlap between the Administrative Court and the pretrial that led to legal uncertainty. So that prudence requires from the law enforcement authorities in the use of criminal sanctions in legislation in the field of public administration with regard to the principle of proportionality and the subsidarity principle. The principle of proportionality requires a balance between the loss to the limits given by the principle of tolerance with the reaction or criminal sanctions provided, which means whether the use of criminal sanctions are causing a greater loss or not, it shows the presence of punishment when used throughpremium remedium against legal violations power abuse can cause a concern/worry for officials or state officials in making a discretionary in urgent circumstances or situations where there are no legal provisions that may impact indirectly led to the lengthy process of bureaucratic or even the services does not meet the public interest.While the subsidarity principles before an act is stated as a criminal act,it is needed to consider whether the legal interests have been violated by an act or policy that contains elements of power abuse that can still be solved by other legal instruments, it is due to the nature of the crime as ultimum remedium.

Therefore, as we know that both provisions of the Government Administration Law (in the realm of administrative law) nor the provisions of the Corruption Eradication Law can be said to be overlapping and can potentially cause overcriminilization especially regarding the discretion that contains elements of power abuse and indemnification of the state losses, so the examination process done with prudence by law enforcement officials is needed. In this case of course it deals with the Heuristics which is an important process in the enforcement of criminal law and administrative law.This process is related to the structuring of facts and structuring rules (Sidharta. 2016: 9). Criminal law enforcement process and examination through the administrative court certainly can not be separated from the Heuristics, because in the criminal proceedings to examine the evidence whether or not there are criminal acts 
starting from the investigation in searching, finding, and at least close to the material truth. Material truth must not be separated from the finding evidence process and restructuring the facts or events which in the criminal proceedings the positions of the law enforcement must culminate in a final decision (litis finiri oportet). Also in the inspection process at the Administrative Court of testing to determine whether the discretion meets the elements of power abuse or not, of course they need to maximize the examinations based on the existing evidence. Because if therestructuring facts and structuring rules in the criminal proceedings as well as tests performed by the administrative court are not done properlyand carefully, it will make no certainty that should be guaranteed by the State, as in the Constitution Law 1945 in Article 28 (1), letter D, which stated "Everyone has the right to recognition, security, protection and legal certainty and equal treatment before the law". In that provision indicates that Indonesia as a country protects its citizens through legal provisions to obtain legal recognition, legal security, legal protection, legal certainty and legal justice. With the absence of legal certainty can also create injustices for Justiabelen.

\section{E. CLOSING}

From the descriptions as mentioned above can be summarized as follows:

1) The main problem which makes an overlapping, overcriminilization and disharmony is the similarity in the formulation of the offense elements of power abuse in the Law on Corruption by the Government Administration Law and make it a lawthat can be approached with a different legal instrument that differ especially the consequences. This is getting worse because of the equalization terminology of power abuse between the realm of administrative law with the realm of criminal law, especially the Law on Corruption Eradication. So with the Law on Government Administration that regulate thepower abuse should be in the realm of the state administration law and the need for a distinction between those two realms of law. Besides that,the use of theCorruption Eradication Law can still be used to catch the perpetrators with certain circumstances that there are the elements of bribery, graft, extortion, nepotism and collusions, accompanied by fulfilling aspects of enormous victim, the defendant residivist, losses can not be recovered ( irreparable) by applying the specialist systematic lex with the requirements above.

2) Legal basis of Article 21 of Law Number 31 Year 2014 about the Goverment Administration giving thepower to the administrative court to examine whether there is an abusive discretionary power or not. This caused the administrative court to 
examine the discretion forum as well as protection for the officials or state officials concerning the criminalization that will happen to them because of the discretionary issuance. However, in practice and post-judgment judicial review of the Constitutional Court to extend the pretrial authority,then the decision of the Administrative Court which has the force of the law can still be examined and brought into the realm of criminal law and led to the examination in pretrial to determine the legitimacy of the establishment of the suspect. To solve that issue, the law enforcement officials needs to refer to the results of the National Workshop that held by the Supreme Court in 2007 and stated that the completion of the Beleidsvrijheid and wijsheid held by any officials or state officials, who have the authority under the legislation that exists. Restrictions on Beleidsvrijheid apply if there are acts that included abuse of power(detourne-ment de pouvoir and abus de droit). The resolution of these irregularities, done through administrative tribunals or administrative courts.In addition, when a discretionary made by public officials or state officials who have been tested and decided by the administrative court to be declared null from the elements of power abuse, or in accordance with the procedures and have permanent legal force, it can not be filed and applied to the realm of criminal law, especially corruption. Unless the law enforcement officials found new evidence in the form of the presence of elements of bribery, graft, collusion and nepotism, enormous victim, defendant residivist, losses can not be recovered (irreparable) at the discretion, it can be submitted to the realm of criminal law either through pretrial as well as to continue the investigations. This is to avoid overlapping competencies between the administrative court and pretrial justice.

\section{BIBLIOGRAPHY:}

\section{Books}

Andhi Nirwanto. 2015. Asas Kekhususan Sistematis Bersyarat Dalam Hukum Pidana Administrasi Dan Tindak Pidana Korupsi. Bandung. Alumni.

Andi Hamzah. 2012. Asas-asas Hukum Pidana Di Indonesia \& Perkembangannya. Medan. Soft Media

Bambang Poernomo 1988. Pola Dasar Teori-Asas Umum Hukum Acara Pidana dan Penegakan Hukum Pidana. Yogyakarta. Liberty.

Chaerudin, Syaiful Ahmad Dinar, Syarif Fadilla, 2008, Strategi Pencegahan \& Penegakan Tidank Pidana Korupsi. 
Eddy OS Hiariej. 2016. Prinsip-Prinsip Hukum Pidana Edisi Revisi. Yogyakarta. Cahaya Atma Pustaka.

Hotma P. Sibuea. 2010. Asas Negara Hukum, Peraturan Kebijakan, dan Asas-Asas Umum Pemerintahan Yang Baik. Jakarta. Erlangga.

Iman Suroso. 2016. Hukum Acara Pidana karakteristik Penghentian Penyidikan dan Implikasi Hukumnya. Yogyakarta. LaksBang Presindo.

Indriyatno Seno Adji. 2009. Korupsi dan Penegakan Hukum. Jakarta. Diadit Media.

J.J.H. Bruggink, Rechtsreflecties, Groundbegrippen uit de rechtstheorie. alih bahasa B Arif Sidharta, 1999, Refleksi tentang Hukum. Bandung Citra Aditya Bakti.

Joel Feinberg. 2003. Problem Roots of Law:Essay in Legal And Politic Theory. New York. Oxford University Press.

Jongker Sihombing. 2009. Tanggung Jawab Yuridis Bankir Atas Kredit Macet Nasabah. Bandung. Alumni.

Lilik Mulyadi, 2012, Bunga Rampai Hukum Pidana Umum dan Khusus, Bandung: Alumni.

Lilik Mulyadi. 2007. Tindak Pidana Korupsi Di Indonesia, Normatif, Teoritis, Praktik dan Permasalahannya. Bandung. Alumni.

M Alli Zaidan. 2016. Kebijakan Kriminal. Jakarta. Sinar Grafika.

Media Indonesia. 2016. Pemerintah Daerah Menjadi Episentrum Kasus Korupsi. Tertanggal 29 Agustus 2016 Hal 5

Moch Iqbal. 2014. Kriminalisasi Kebijakan Pejabat Publik. Jakarta. Puslitbang Hukum dan Peradilan Badan Litbang Diklat Kumdil Mahkamah Agung RI.

Ni’matul Huda. 2005. Negara Hukum, Demokrasi \& Judicial Review. Yogyakarta. UII Press.

Nurbasuki MinarNumber 2010. Penyalahgunaanwewenang Dalam Pengelolaan Keuangan Dareah Yang Berimplikasi Tindak Pidana Korupsi. Surabaya. Laksbang Mediatama.

O.C. Kaligis. 2012. Antologi Tulisan Ilmu Hukum:Jilid 8. Bandung. Alumni. 2015. Pencegahan dan Pemberantasan Korupsi Dalam Tugas Kedinasan (Pasca UU No 30 Tahun 2014). Bandung. Alumni.

Ridwan.2014 Diskresi \& Tanggungjawab Pemerintah. Yogyakarta. UII Press

Romili Atmasasmita. 2010. Globalisasi \& Kejahatan Bisnis, Cet 1. Jakarta. Kencana Prenada Media. 
Sidharta. 2016. Heurestika dan Hermeneutika: Penalaran Hukum Pidana. Artikel pada Demi Keadilan Antologi Hukum Pidana dan Sistem Peradilan Pidana: 6 Dasawarsa Harkristuti Harkrisnowo. Jakarta:Pustaka Kemang.

Soerjono Soekanto dan Sri Mamuji. 2007. Penelitian Hukum Normatif Suatu Tinjauan Singkat. Jakarta: Rajawali Press

Sri Soemantri. 1992. Bunga Rampai Hukum Tata Negara Indonesia. Bandung. Alumni.

Sudarto. 1981. Kapita Selekta Hukum Pidana. Bandung. Alumni.

\section{Scientific Paper}

Muladi. Proyeksi Hukum Pidana Materiil Indonesia di Masa Mendatang, Pidato Pengukuhan Jabatan Guru Besar Ilmu Hukum Pidana pada Fakultas Hukum Universitas Diponegoro, Semarang 24 Februari 1990

Syukri Asy'ari, Meyrinda Rahmawaty Hilipito, Mohammad Mahrus Ali. 2012. Model dan Implementasi Putusan Mahkamah Konstitusi Dalam Pengujian Undang-Undang (Studi Putusan tahun 2003-2012). Jakarta: Pusat Penelitian dan Pengkajian Perkara Pengelolaan Teknologi Informasi Dan Komunikasi Kepaniteraan dan Sekertariat Jenderal Mahkamah Konstitusi RI.

Yulius. 2015. Menyelisik Makna Penyalahgunaan Wewenang Dalam Undang-Undang Administrasi Pemerintahan Di Tinjau Dari Opti Hermeneutika Hukum. Varia Peradilan No 360 November 2015.

Zudan Arif Fakrullah. 2015. Tindakan Hukum Bagi Aparatur Penyelenggara Pemerintahan. Seminar Nasional IKAHI ke 62 Jakarta 26 Maret 2016.

\section{Internet}

http://nasional.kompas.com/read/2016/06/28/17363961/ma.tolak.pk.yang.diajukan.kpk.atas.p raperadilan.hadi.poernomo di unduh pada tanggal 28 Juni 2015

http://www.gresnews.com/berita/hukum/210125-/0/ diunduh atau diakses pada tanggal 1 Januari 2016

http://news.detik.com/berita/3300015/tak-terima-jadi-tersangka-kpk-gubernur-sultra-nuralam-ajukan-praperadilan diakses pada tanggal 16 september 2016

http://www.brainyquote.com/quotes/quotes/m/martinluth297518.html diakses pada tanggal 15 Juni 2015 
http://www.hukumonline.com/klinik/detail/lt51fb46e7a8edc/cara-menentukan-adanyakerugian-keuangan-negara di akses pada tanggal 10 Juli 2015

Lilik Mulyadi. 2012. Dimensi dan Implikasi "Perbuatan Melawan Hukum Materiel Dalam Hukum Tindak Pidana Korupsi pada Putusan Mahkamah Agung Pasca Putusan Mahkamah Konstitusi $R I$, http://pnkepanjen.go.id/index.php?option=com_content\&view=article\&id=110: di Unduh pada tanggal 1 September 2016

Muchamad Ali Safa'at, tanpa tahun, Kekuatan Mengikat Dan Pelaksanaan Putusan MK, Makalah, Malang Universitas Brawijaya, hlm 2. Muchamad Ali Safa'at, Penafsiran Konstitusi, diunduh dari http://safaat.lecture.ub.ac.id/2011/11/penafsiran-konstitusi/ , diakses pada tanggal 5 Mei 2015

http://www.hukumonline.com/berita/baca/hol14123/theo-toemion-jadi-tersangka-korupsi diakses pada tanggal 6 juni 2015

https://nasional.tempo.co/read/news/2006/08/25/05582614/theo-toemion-divonis-6-tahun diakses pada tanggal 6 Juni 2015

https://id.wikipedia.org/wiki/Theo_Toemion\#Kasus_korupsi diakses pada tanggal 6 Juni 2015

http://www.jpnn.com/read/2012/12/11/149981/Rokhmin-Dahuri,-Bekas-Menteri-yangPertama-Dijerat-KPK- diakses pada tanggal 6 September 2015

\section{Regulations:}

Law Number 31 of 1999 Jo Law Number 20 Year 2001 OnCorruptionEradication

Law Number 30 of 2014 On Government Administration

Supreme Court Regulation Number 4 of 2015 on The Procedural Law of the Abuse Authority 